\title{
The Perception of Using Language in Gender Disparity: A Study on Tertiary Level Students
}

\author{
Serajum Munira ${ }^{1}$, Amzad Hossain $^{2} \&$ Meherun Nessa ${ }^{3}$ \\ ${ }^{1}$ Department of English, Green University of Bangladesh \\ ${ }^{2}$ Department of Sociology, Government Edward College, National University, Bangladesh \\ ${ }^{3}$ Department of Language (English), Shere-e-Bangla Agricultural University, Bangladesh \\ Correspondence: Md. Amzad Hossain, Lecturer, Department of Sociology, Government Edward College, \\ National University, Bangladesh.
}

Received: October 15, 2019

Accepted: December 26, 2019

Online Published: February 4, 2020

doi:10.20849/ajsss.v5i1.708

URL: https://doi.org/10.20849/ajsss.v5i1.708

\begin{abstract}
The present study aims at exploring the extent of linguistic varieties which are issues of gender disparity in our society. Language is the most advanced form of communication possessed only by human beings. Linguistic elements direct our expressions, feelings and thoughts, and languages even help us transmit knowledge, ideas and beliefs from one generation to another. In fact, language is systematic as it follows rules. However, it is believed that men and women have a strong natural tendency to use different patterns of a language. Relationship between language and gender attracted many researchers' attention, but some critics of mid-twentieth century considered such studies to be purely feministic. With the passage of time, our social structure met considerable changes which influenced our languages. The objective of this project is to give reasonable answers to the questions regarding the gender based speech differences in today's world. Survey method was applied in order to maintain high standards of research ethics and maintain the research quality. This study engages 384 respondents; among them $51 \%$ were male and $49 \%$ were female. According to the survey data, $68 \%$ of the participants reported that women always tend to use exaggerated expressions and words that can assist in building rapport. Further, it finds out whether there is any difference between speech patterns of different age groups coming from the same gender. By delving into both historic and contemporary documents, this experiment will lead us to widen the scope of research on various ways of communication.
\end{abstract}

Keywords: socio-economic status (SES), gender disparity, linguistic variety

\section{Introduction}

Language and gender relationship has been a key subject to study for a large number of researchers from different fields like applied linguistics, linguistics, sociolinguistics, anthropology, cultural studies, conversational analysis, gender studies, feminist psychology, stylistics and so on. There are some researches which have simultaneously examined the contribution of child sex and family, socio-economic status (SES) to language development, but studies on how these factors interact are extremely rare. A longitudinal survey has assessed overall language comprehension between 18 and 36 months in a large cohort of diverse SES and data for this study were collected through a brief maternal report consisted of five items for 18 months and seven items for 36 months (Zambrana et al., 2012). According to the authors, sex differences increase with the decreasing level of maternal education. They further claim that mothers' educational attainment put a greater impact on change in language comprehension across ages in boys than in girls. However, it was not reported whether maternal education has any effect on young children's (18 months) vocabulary production and comprehension (Berglund et al., 2005) or on older children's (between 24 and 48 months) lexical productivity and diversity (Le Normand et al., 2008). Therefore, it is yet to discover whether gender differences are consistent across the socioeconomic strata after age 3 and how SES affects child language in relation to their sex across early childhood.

Men's and women's language are regular phenomena in gender differentiation in language. But when it comes to the linguistic study of changes within language, it is quite recently sociolinguistic factors have been taken into consideration. Coates believes that linguistic change takes place in the context of linguistic heterogeneity. However, before it is claimed that a new linguistic form has come into form, that linguistic change should be 
practiced by some sub-group within a speech community. In addition to that, this new form has to be adopted by other members of that community and accepted as a norm.

Stéphanie Barbu et al. (2015) detected repetitive exercise of Child sex and family SES as a source of inter-individual variation in language development. But exploring their interactions has been a rare task. When sex differences are the core aspects concerning emerging language skills, data remain scarce and are not consistent throughout preschool years. Some other questions arise as to whether family SES has equal impact on boys and girls and if these differences are consistent across early childhood. They assessed the consistency of sex differences throughout SES and age by focusing on how children from two different social backgrounds acquire a frequent phonological alternation in French - the liaison. They found evidence of sex differences over the preschool years in low-SES children. On the other hand, there was no noticeable difference between high-SES boys and girls, rather their performances were quite similar. Performances of low-SES boys were the poorest whereas performances of low-SES girls were intermediate. In other words, low-SES girls' performances were lower than those of high-SES children (both sexes) and higher than those of low-SES boys. Though all children's mastery of obligatory liaisons improved with age, findings of their study presented significant impeding effect of low-SES, especially on boys.

There are some frequent factors which lead to linguistic variation in all known societies. One of those aspects is social variation which is distinguishing people's affiliation regarding social class. Apart from that there is another variation known as stylistic variation which refers to the speech of an individual in different contexts. Studying language in its social context requires focus on linguistic variation which is largely dependent on the environment in which the speaker finds himself or herself. Language of different individuals varies depending on the following criteria: age, gender, social class and ethnic groups.

It is assumed that a speaker, regardless of his/her gender, adjusts himself or herself to the situation in order to 'fit in'. To put it simply, the way we speak is influenced by several factors. The neo grammarians of nineteenth century argue that linguistic change was caused by the twin techniques of sound change and analogy. They claim that the system was altered by the sound change and the system was made regular again by the analogy. However, there is a group of linguists known as functionalists who came up with another explanation for the changes within language. They 'argued that change occurs because of the opposing demands of the need to communicate and the desire to make as little effort as possible' (Coates, 1993: 168-170). Though their views about the possible reasons of changes in language are not alike, both of these groups show great interest in language. Language, however, should not be considered as a 'thing'. Language and its users should not be looked at in isolation. Researchers, who are not segregated into different 'camps', provide the same opinion about the male and female speech patterns.

Moreover, another variation studied are dialects in a language. Dialectologists focus on changing aspects of pronunciation and lexical resources within a language system. They also investigate changeable patterns of bilingualism. As languages change, it is important to record the data regarding rural dialects before they cease to exist. It was a major research question for the dialectologists of early nineteenth century whether women played any vital role in changing languages. According to Gauchat, a dialectologist, old inhabitants of a village in Switzerland use the forms (of the dialect of Charmey) that are phonetically older than those used by young ones. His research presents another important point that women use more advanced pronunciation in comparison with men. So, women can be considered as innovatory force, whereas men can be taken as conservative force. As women are willing to accept and adopt the change, their language pattern has a great impact on the language of the young. Therefore, women are the natural initiators of linguistic change (Coates, 1993: 169-171).

Long back in 1922, Otto Jespersen conducted a research to find out whether women speak differently compared to men. His study suggests that women much more often than men break off without completing their sentences, because they initiate speaking without having any idea about what they are going to say (Jespersen 1922: 250). Though one can regard Jespersen's view to be a biased conviction as he referred to women as one group and did not classify women according to their age, social class and academic achievement, still he has a point in his remark regarding 'half-finished' sentences which will be discussed later in this essay.

Professor Barrie Throne and Professor Nancy Henley, focusing on 'Sociology and Women's studies' and 'language and non verbal communication' respectively, declared that 'women compared with men of the same social class, age and level of education, more often choose the form closer to the prestige, or "correct" way of talking' (Thorne, Henley, 1975: 17). Another researcher, Peter Trudgill, also viewed in the same that women speak a form of language which is closer to standard language or carries higher prestige. His study further provided with one possible explanation as to what influenced women to trigger such language pattern, 'namely 
because women were not rated by their occupations which is why other signals of status, including speech are correspondingly more important' (Trudgill, 1975: 92). According to Trudgill, women are better speakers than men. Spender added a little more detail that women are more polite, less forceful and technically more correct performers (Spender, 1980: 36-38).

A good number of questions arise when language is examined based on a sociolinguistic aspect. Such as, 'ordinary language' is used to do the talking, but there is also something which can be called either 'hidden language' or 'silent language'. In other words, all speakers do not apply the same strategies to get their way. There are plenty of works on how people interact with each other- yet the question remains as to whether it is possible to identify differences between the strategies used by men and women.

H.T. Moore (1922) viewed that men talked about their work more frequently than women did. As women usually worked at home mostly and outside rarely, men would tend to use words linked to their work outside their home. Moore also stated that words related to men's work were serious, whereas words used by women were trivial (Spender, 1980: 34).Moore's point is analogous to that of Jespersen that at that time women's language was more narrowed and restricted. If the school-system is taken into consideration, it appears that women were not allowed to participate at the same level as men did. Therefore, it is apparent that men enjoyed most of the opportunities in the field of work and education. Women did not have access to tasks of generating the forms of thought and the images and symbols in which ideas are presented and ordered (Klein \& Steinberg, 1989: 3-11).

According to Smith (1978), since males primarily contributed to the rise of cultural forms and images in human society, it would be surprising if language change were not their subject. She discussed about a circle effect: 'What men were doing was relevant to men, was written by men about men for men' (Klein \& Steinberg, 1989: 4). Her explanation indicates that tradition is formed through thought which develops by means of language: written, printed as well as oral form.

\subsection{Objectives of the Study}

a) To know the perception of using language in gender disparity

b) To find out the communication differences between male \& female

c) To explore gender differences in conversation in daily activities

\section{Methodology}

This exploratory research utilized quantitative methods including structured survey. The use of methods permitted the data to improve the validity of the findings and enable greater inferences from the results.

\subsection{Study Population}

In this study there were five different types of target populations. The following target populations were included in the study-undergraduate students of $1^{\text {st }}, 2^{\text {nd }}, 3^{\text {rd }} \& 4^{\text {th }}$ year and graduate students of various universities.

\subsection{Data Collection Methods}

Survey data collection methods were used in this study. In addition, to collect data the researchers spent 3 months of period in the field. During that time, the researchers made a rapport with the people of the study area.The aim of the study was to have an insight that helped to decide research method and develop hypothesis, interview schedule, in social mapping of sampling design and to select a right person to collect data from the desired respondents.

\subsection{Sampling Procedure, Sample Size Determination and Study Area}

Probability sampling approach was followed for conducting survey for the quantitative part of this study. Particularly, random sampling procedure was adopted to draw sample for the survey. As mentioned earlier, this study was conducted in Dhaka city urban area and the unit of analysis was the tertiary level students. The total number of respondents under study area is 384 and all the respondents were considered as the sampling frame from which the required number of sample was drawn. The sample size was estimated through an approach based on confidence level and precision rate. For this purpose the general formula of Fisher was used with the following assumptions.

If the sample respondent was not available at the time of survey, then at least two revisits would make to interview the sample respondents. However, there were cases of non-response from respondents including cases of non-availability of respondents in selected area. In this situation, the interviewers selected alternative respondent from the next third household so that the overall sample size is achieved, which is given a brief account in sampling procedures. Therefore, the overall non-response rate in this study is virtually zero. 
Structured survey was served as the main data collection method of this study. With the objective to organize this work in a representative manner, the researchers divided the study areas into six Zones on the basis of the residential and commercial areas. From various Zones the sample were collected by the survey as there was no defined target population list. Thus a total number of 384 samples were selected from the six Zones of the Dhaka city.

\section{Ethical Consideration}

To conduct this study the informed consent form was signed and obtained from the respondents. Confidentiality of the respondents was maintained at all times. Anonymity was maintained by not disclosing the identity of the respondents. Participation was voluntary and the respondents were informed that they could withdraw from the study at any stage.

\section{Findings of the Study}

Finding1. Demographic uni-variate variables

\begin{tabular}{|c|c|c|c|}
\hline Variables & Category & Frequency & Percent \\
\hline \multirow[t]{2}{*}{ Sex of the respondents } & Male & 188 & 49.0 \\
\hline & Female & 196 & 51.0 \\
\hline \multirow[t]{5}{*}{ Age of the respondents } & $15-20$ & 199 & 51.8 \\
\hline & $20-25$ & 100 & 26.0 \\
\hline & $25-30$ & 31 & 8.1 \\
\hline & $30-35$ & 46 & 12.0 \\
\hline & $35+$ & 8 & 2.1 \\
\hline \multirow[t]{2}{*}{ Marital Status } & Married & 35 & 9.11 \\
\hline & Unmanied & 349 & 90.88 \\
\hline \multirow[t]{2}{*}{ Religion of the respondents } & Muslim & 329 & 85.7 \\
\hline & Hindu & 55 & 14.3 \\
\hline \multirow[t]{5}{*}{ Education of the respondents } & First year & 90 & 23.4 \\
\hline & Second Year & 114 & 29.7 \\
\hline & Third Year & 77 & 20.1 \\
\hline & Fourth Year & 82 & 21.4 \\
\hline & Master & 21 & 5.5 \\
\hline \multirow[t]{6}{*}{ Income of the respondents } & $<1500$ & 124 & 32.3 \\
\hline & $1500-2400$ & 110 & 28.6 \\
\hline & $2400-3400$ & 73 & 19.0 \\
\hline & $3400-4400$ & 49 & 12.8 \\
\hline & $4400-5400$ & 21 & 5.5 \\
\hline & $5400+$ & 7 & 1.8 \\
\hline
\end{tabular}


Finding 2. Bi-variate table

\begin{tabular}{|c|c|c|c|}
\hline $\begin{array}{l}\text { variable } \\
\text {. }\end{array}$ & Frequency & percent & Cumulative frequency \\
\hline \multicolumn{4}{|c|}{ Female use more intensifies than male } \\
\hline Yes & 216 & 56.3 & 56.3 \\
\hline No & 168 & 43.8 & 100 \\
\hline \multicolumn{4}{|c|}{ Men use more slang expression than women } \\
\hline Yes & 242 & 63.0 & 63.0 \\
\hline No & 142 & 37.0 & 100 \\
\hline \multicolumn{4}{|c|}{ Women pay more attention to language elegancy } \\
\hline Yes & 194 & 50.5 & 50.5 \\
\hline$\overline{\text { No }}$ & 190 & 49.5 & 100 \\
\hline \multicolumn{4}{|c|}{ Women use more tag question than man } \\
\hline Yes & 203 & 52.9 & 52.9 \\
\hline No & 181 & 47.1 & 100 \\
\hline \multicolumn{4}{|c|}{ Women speak more sensitivity on speaking } \\
\hline Yes & 205 & 53.4 & 53.4 \\
\hline No & 179 & 46.6 & 100.0 \\
\hline \multicolumn{4}{|c|}{ Men use non- standard forms of voice more than women. } \\
\hline Yes & 204 & 53.1 & 53.1 \\
\hline$\overline{\text { No }}$ & 180 & 46.9 & 100.0 \\
\hline
\end{tabular}

Finding 3. Association between demographic variable and female tone is higher than males

\begin{tabular}{lll}
\hline \multirow{2}{*}{ Socio-demographic variables } & Female tone is higher than males & \\
\cline { 2 - 3 } Sex & Crame' V Value & Chi-square Value \\
Age & $\mathrm{V}=0.95^{* * *}$ & $\mathrm{X}^{2}=15.90^{* * *}, \mathrm{df}=4$ \\
\hline Marital Status & $\mathrm{V}=0.10$ & \\
\hline Education & $\mathrm{V}=0.92^{* * *}$ & $\mathrm{X}^{2}=4.2^{* * *}, \mathrm{df}=3$ \\
\hline Religion & $\mathrm{V}=0.21^{*}$ & $\mathrm{X}^{2}=4.36^{* *}, \mathrm{df}=2$ \\
\hline Occupation & $\mathrm{V}=0.00$ & \\
\hline Income & $\mathrm{V}=0.10$ & \\
\hline
\end{tabular}

$* * * \mathrm{P}=0.10 ; * * \mathrm{P}=0.01 ; * \mathrm{P}=0.05$

Finding 4. Association between demographic variable and men use non-standard forms of voice more than women

\section{Socio-demographic variables Men use non- standard forms of voice Chi-square Value} more than women. (Cramer's v)

\begin{tabular}{llc}
\hline Sex & $\mathrm{V}=0.46^{* *}$ & $\mathrm{X}^{2}=11, * * * \mathrm{df}=3$ \\
\hline Age & $\mathrm{V}=0.10$ & \\
\hline Marital Status & $\mathrm{V}=0.48 * * *$ & $\mathrm{X}^{2}=4, * * * \mathrm{df}=5$ \\
\hline Education & $\mathrm{V}=0.11$ & \\
\hline Religion & $\mathrm{V}=0.16$ & $\mathrm{X}^{2}=12 * *, \mathrm{df}=3$ \\
\hline Occupation & $\mathrm{V}=0.19$ & \\
\hline Income & $\mathrm{V}=0.89 * * *$ & $\mathrm{X}^{2}=11 *, \mathrm{df}=2$ \\
\hline
\end{tabular}

$* * * \mathrm{P}=0.10 ; * * \mathrm{P}=0.01 ; * \mathrm{P}=0.05$ 
Finding 5. Association between demographic variables and female use more intensifies than male

\begin{tabular}{lll}
\hline Socio-demographic variables & $\begin{array}{l}\text { Female use more intensifies than Chi-square Value } \\
\text { male (Cramer's v) }\end{array}$ & \\
\hline Sex & $\mathrm{V}=0.21 *$ & $\mathrm{X}^{2}=8.56 * * *, \mathrm{df}=2$ \\
\hline Age & $\mathrm{V}=0.58 * * *$ & $\mathrm{X}^{2}=9.16, * \mathrm{df}=2$ \\
\hline Marital Status & $\mathrm{V}=0.23$ & \\
\hline Education & $\mathrm{V}=0.11$ & $\mathrm{X}^{2}=16.21 * * *, \mathrm{df}=4$ \\
\hline Religion & $\mathrm{V}=0.11$ & \\
\hline Occupation & $\mathrm{V}=0.12$ & $\mathrm{X}^{2}=9.48, * * \mathrm{df}=3$ \\
\hline Income & $\mathrm{V}=0.41 * *$ & \\
\hline$* * \mathrm{P}=0.10 ; * * \mathrm{P}=0.01 ; * \mathrm{P}=0.05$ & &
\end{tabular}

Finding 6. Association between demographic variable and women use more tag question than man

\begin{tabular}{lll}
\hline Socio-demographic variables & $\begin{array}{l}\text { Women use more tag question than Chi-square Value } \\
\text { men (Cramer's v) }\end{array}$ & $\mathrm{X}^{2}=11 * * *, \mathrm{df}=5$ \\
\hline Sex & $\mathrm{V}=0.94 * * *$ & $\mathrm{X}^{2}=12, * * \mathrm{df}=3$ \\
\hline Age & $\mathrm{V}=0.59 * * *$ & \\
\hline Marital Status & $\mathrm{V}=0.50 * *$ & \\
\hline Education & $\mathrm{V}=0.17$ & $\mathrm{X}^{2}=3 * * *, \mathrm{df}=1$ \\
\hline Religion & $\mathrm{V}=0.66 * * *$ & \\
\hline Occupation & $\mathrm{V}=0.83 * * *$ & $\mathrm{X}^{2}=4.5 *, \mathrm{df}=2$ \\
\hline Income & $\mathrm{V}=.68 * * *$ & \\
\hline
\end{tabular}

$* * * \mathrm{P}=0.10 ; * * \mathrm{P}=0.01 ; * \mathrm{P}=0.05$

\section{Discussion and Conclusion}

This survey included 384 respondents; among them 51 percent were male and 49 percent female. Most of the students' age was below 29 years. The marital status of the respondents reveals that $73.2 \%$ were unmarried and 26. $8 \%$ students were married.

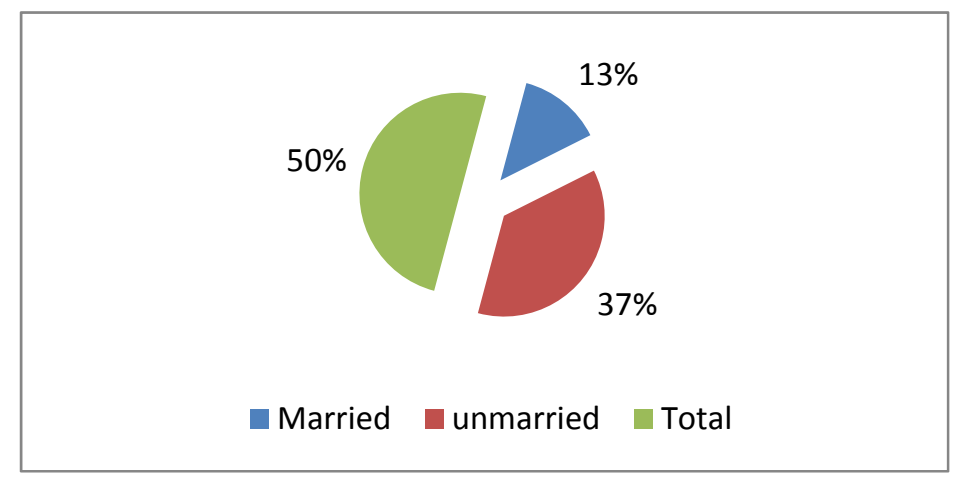

The age distribution of the respondents reveals that more than half (80\%) of the respondents belonged to the age group of more than 25 years of age while 20 percent students were in the age group of less than 29 years. 


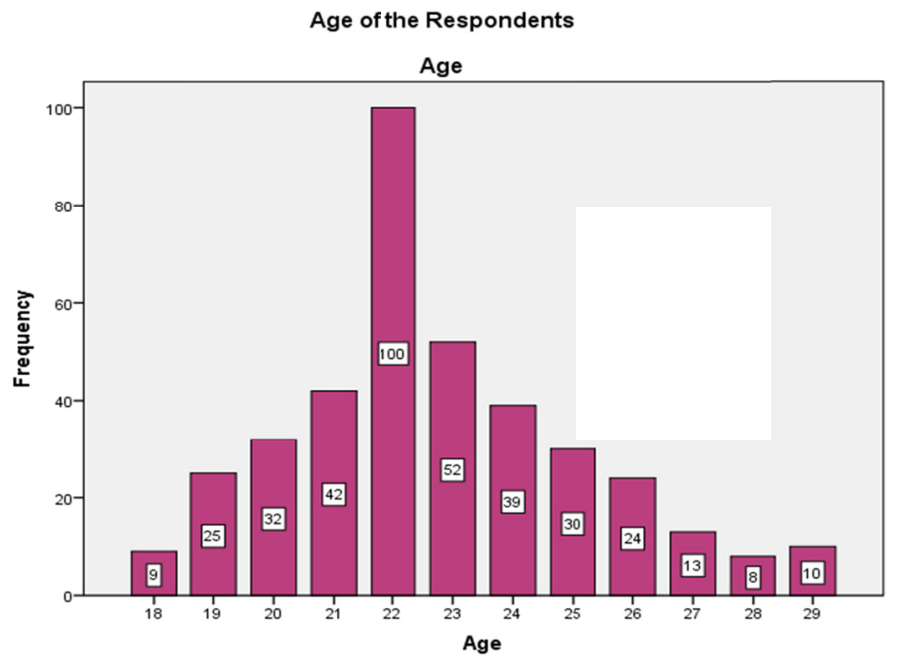

Figure 1. Age of the respondents

The income of the respondents clearly shows their below \& upper-class position in the society. It has been observed that 32.3 percent of the students have a gross monthly income less than 3000 taka and the rest have higher than 3400 taka per month. The study findings also suggest that the tertiary level female students are accustomed to use more intensifiers than male.

The study explores that $68 \%$ respondents reported that women always use words with significant exaggeration such as gorgeous, lovely, cute, adorable, darling, sweetheart and so on. These are the elements of the language that women use, as identified by Robin Lakoff in 1975. Of course, not all women use all of these forms of language all the time, and some may question the whole. The study shows that $50.5 \%$ respondents replied that women use more hedges than male and $49.5 \%$ said, women do not use more hedges than men. It would be interesting to do a duplicate study now and see how much of this has changed since the 1970s. Hedging provides a way out, should disagreement occur, qualifying statements with non-absolute language, such as 'sort of', 'I guess'; 'well'; 'I sort of looked at him, and then he kind of looked back and then I guess I kept looking' etc.

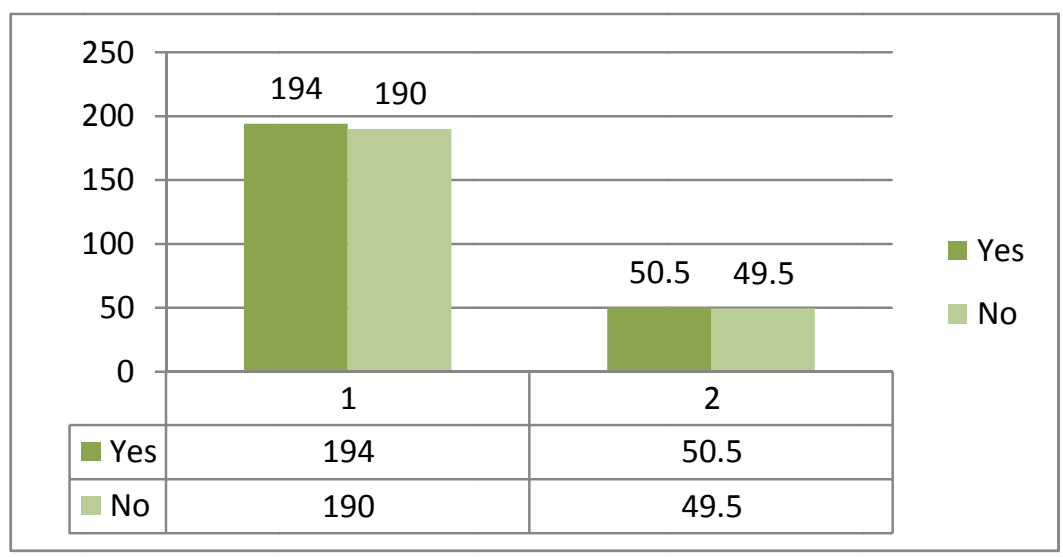

Figure 2.Women use more hedges than men

It is known that language issue is a very diverse concept which contains many ideas that indicates different types of individual characteristics. Hence, here the researchers tried to find out some of those issues that indicate language aspects directly and by conducting a questionnaire survey they found some answer of specific data that might indicate and fulfill the main objectives of the research. 


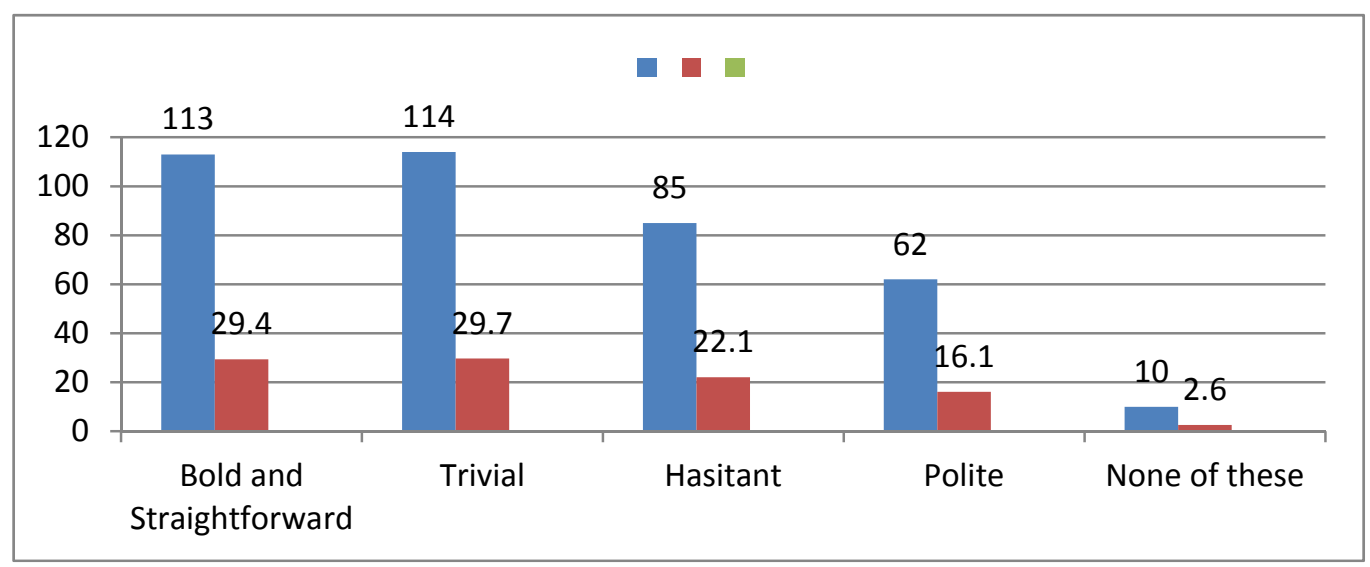

Figure 3. Men's language use is perceived as

The study shows that the female respondents $50.5 \%$ said that they pay more attention to language elegancy. In this study all the quantitative findings are presented using both bivariate techniques. In the case of bivariate analysis cross tables are formed using SPSS and the statistical relations between variables are tested by using a number of appropriate measures of association. Chi-square test is applied for nominal level variables. When variables are nominal in nature and the table is larger than $2 \times 2$ formats with having any cell frequency less than 5 then V is applied (Bryman, 2004).Table 3 shows the statistical association between a set of independent variables and seven dependent variables. The findings of the study established that sex, marital status and income of the respondents was strongly associated with the female tone is higher than that of the male. It indicates that the respondents having higher income is more likely to be aware of female tone is higher than male. Moreover, sex, marital status, income $(\mathrm{P}=<0.10)$ and education $(\mathrm{P}=<0.01)$ are strongly correlated with Female tone is higher than the males as well (as table 6 shows).

An effort was completed to investigate the association between men's and women's language use on the basis of standard forms of voice through the socio-demographic characteristics of the respondents. In this section an exact association among some socio-demographic characteristics such as sex, age, marital status, religion as well as occupation has been found. The results of the association as presented in the previously drawn tables, indicate that students having higher level of education, higher level of income tend, women use more tag questions than men. It is known that cultural issue is a very diverse concept which contains many ideas that indicates different types of individual characteristics. Ultimately, it can be concluded that, this paper has reached in point that a lot of important issues that are the effect of gender socialization, is not a curse to the society but it can bring a lot of positive and negative effects along with culture which is an impending issue to govern the people into a same premises and gender which is a powerful real aspect of the new world system, and it represents one of the most influential forces in determining the future course of the planet. It has manifold dimensions as economic, political, environmental, social, cultural, health and security related issues.

\section{References}

Barbu, S., Nardy, A., Chevrot, J. P., Guellaï, B., Glas, L., Juhel, J., \& Lemasson, A. (2015). Sex differences in language across early childhood: Family socioeconomic status does not impact boys and girls equally. Front. Psychol, 6, 1874.

Berglund, E., Eriksson, M., \& Westerlund, M. (2005).Communicative skills in relation to gender, birth order, childcare and socioeconomic status in 18-month-old children. Scand. J. Psychol, 46, 485-491.

Bergvall, V. (1996). The Question of Questions: Beyond Binary Thinking. In V. Bergvall, J. Bing, \& A. Freed (Eds.), Rethinking Language and Gender Research: Theory and Practice (pp. 1-30). New York: Longman.

Butler, J. (1993). Bodies that Matter: On the Discursive Limits of Sex. New York: Routledge.

Cameron, D. (1977). Performing gender identity: Young men's talk and the construction of heterosexual masculinity. In S. Johnson, \& U. H. Meinhof (Eds.), Language and masculinity. England, UK: Blackwell.

Cameron, D. (1995). Rethinking Language and Gender Studies: Feminism into the 1990s. In S. Mills (Ed.), Language and Gender: Interdisciplinary Perspectives. London: Longman. 
Cameron, D. (1996). The Language-gender Interface: Resisting Co-optation. In V. Bergvall, J. Bing, \& A. Freed (Eds.), Rethinking Language and Gender Research: Theory and Practice. New York: Longman.

Cameron, D. (Ed.) (1990). The Feminist Critique of Language: A Reader. New York: Routledge.

Coates, J. (1986). Women, Men and Language. Harlow, Essex: Longman.

Coates, J. (1998). Thank God I'm a woman: The construction of differing feminities. In D. Cameron (Ed.), The feminist critique of language: A reader (2nd ed., pp. 295-320). USA \& Canada: Routledge.

Coates, J., \& Cameron, D. (Eds.) (1988).Women in their speech communities. London: Longman.

Deuchar, M. (1988). A pragmatic account of women's use of standard speech. In J. Coates, \& D. Cameron (Eds.), Women in their speech communities: New perspective on language and sex. London: Longman.

Eckert, P., \& McConnel-Ginet, S. (1995). Constructing meaning, constructing selves: Snapshots of language, gender and class from Belten High. In M. Bucholtz, \& K. Hall (Eds.), Gender articulated: Language and the culturally constructed self. New York: Routledge.

Eckert, P., \& McConnell-Ginet, S. (1992). Think practically and look locally: Language and gender as community-based practice. Annual Review of Anthropology, 21, 461-490.

Eckert, P., \& McConnell-Ginet, S. (2003). Language and gender. New York: Cambridge University Press.

Fairclough, N. (1989). Language and Power. London: Longman.

Freeman, R. D., \& McElhinny, B. (1996).Language and gender. In S. Mckay, \& N. Hornberger (Eds.), Sociolinguistics and language teaching (pp. 218-280). Cambridge: Cambridge University Press.

Goodwin, M. (1998). Cooperation and competition across girls' play activities. In J. Coates (Ed.), Language and gender: A reader (pp. 121-146). Oxford: Blackwell Publishers.

Henley, N., \& Kramarae, H. (1991).Miscommunication, gender and power. In N. Coupland, J. Wiemann, \& H. Giles (Eds.), Miscommunication and problematic talk (pp. 18-43). Newbury Park, CA: Sage Publications.

Holmes, J. (1984). Women's language: A functional approach. General Linguistics, 24(3), 149-178.

Jaggar, A. M. (1983). Feminist Politics and Human Nature. Totowa: Rowman \& Allanheld.

Karlsson, S. (2007).Gender-related differences in language use.

Kramarae, C., \& Treichler, P. A. (1990).Power relationships in the classroom. In S. Gabriel, \& I. Smithson (Eds.), Gender in the classroom: Power and pedagogy (pp. 41-59). Urban-Champaign: Illinois University Press.

Lakoff, R. (1975). Language and women's place. Harper \& Row, New York. Reprinted in D. Cameron (Ed.) (1998), The feminist critique of language (2nd ed.). London \& New York: Routledge.

O'Loughlin, K. (2000). The Impact of Gender in the IELTS oral interview. IELTS annual report (pp. 1-28).

Ochs, E. (1993). Constructing social identity: A language socialization perspective. Research on Language and Social Interaction, 26(3), 287-306.

Sunderland, J. (2004). Gendered Discourse. New York: Palgrave Macmillan.

Tannen, D. (1990). You just don't understand: Women and men in conversation. New York: William Morrow.

Uchida, A. (1998). When differences is dominance: A critique of the anti-power based cultural approach to sex differences. In D. Cameron (Ed.), The feminist critique of language. USA \& Canada: Routledge.

West, C., \& Zimmermann, D. (1987). Doing gender. In Gender and Society (pp. 125-151).

Zambrana, I. M., Ystrom, E., \& Pons, F. (2012). Impact of gender, maternal education, and birth order on the development of language comprehension: a longitudinal study from 18 to 36 months of age. J. Dev. Behav. Pediatr, 33, 146-155.

\section{Copyrights}

Copyright for this article is retained by the author(s), with first publication rights granted to the journal.

This is an open-access article distributed under the terms and conditions of the Creative Commons Attribution license (http://creativecommons.org/licenses/by/4.0/). 